\title{
Phylogenetic analysis of the pearlfish tribe Carapini (Pisces: Carapidae)
}

\author{
E. Parmentier, ${ }^{1}$ G. Castillo, ${ }^{2}$ M. Chardon ${ }^{1}$ and P. Vandewalle ${ }^{1}$
}

\author{
${ }^{1}$ Laboratory of Functional and \\ Evolutionary Morphology \\ Chemistry Institute B6 \\ University of Liège \\ Sart-Tilman \\ B-4000 Liège \\ Belgium \\ ${ }^{2}$ Laboratory of Algology \\ Mycology and Experimental Systematics \\ Botany department \\ University of Liège \\ Sart-Tilman (B22) \\ B-4000 Liège \\ Belgium
}

\section{Keywords:}

phylogeny, Carapidae, ecomorphology,

skull, head muscle

Accepted for publication:

25 April 2000

\begin{abstract}
Parmentier, E., Castillo, G., Chardon, M. and Pandewalle, P. 2000. Phylogenetic analysis of the pearlfish tribe Carapini (Pisces: Carapidae). - Acta Zoologica (Stockholm) 81: 293-306
\end{abstract}

Fishes of the tribe Carapini (Encheliophis and Carapus) share a noteworthy peculiarity: they shelter in holothurian echinoderms or bivalve hosts. Some species are considered parasitic, others commensal. This study focuses on the phylogeny of the tribe, using two other Carapidae species as an outgroup (Snyderidia canina and Onuxodon fowleri). Insofar as possible, the selected anatomical and behavioural characters where chosen in an ecomorphological perspective, as features that could be responses to various lifestyle-related constraints. Our character selection also took into account the fact that some features are (presumably) linked. Such features were grouped together as a single trait to avoid their overvaluation.

This methodology enabled commensals to be separated from parasites, the former belonging to Carapus and the latter to Encheliophis. Carapus species reflect in their morphology the constraints imposed by a diet of hard, mobile, elusive prey, showing predator-type features: a strong dentition, a wide mouth opening, a robust food intake apparatus. On the other hand, the endoparasitic Encheliophis species show a generally weaker buccal apparatus and narrow mouth opening, in relation to the different constraints of their lifestyle where the diet constraints are less pronounced: they eat body parts of their host. Changes in both generic diagnoses are proposed and three species are transferred from Encheliophis to Carapus.

E. Parmentier, Laboratory of Functional and Evolutionary Morphology, Chemistry Institute B6, University of Liège, Sart-Tilman, B-4000 Liège, Belgium

\section{Introduction}

The family Carapidae comprises two subfamilies (Markle and Olney 1990; Nelson 1994): the Pyramodontinae (two genera: Snyderidia Gilbert and Pyramodon Smith and Radcliffe) and the Carapinae, divided into two tribes: the Echiodontini (three genera: Eurypleuron Markle and Olney, Echiodon Thompson and Onuxodon Smith) and the Carapini (two genera: Carapus Rafinesque and Encheliophis Muller). In this paper we aim to reassess the phylogeny of the Carapini tribe and the generic placements of its included species. Two other Carapidae species (Snyderidia canina and Onuxodon fowleri) were used as outgroups. Known and new features are integrated and related characters are taken into account where possible.
According to Markle and Olney (1990), three features can be used to distinguish the two Carapini genera: Carapus species are characterized by 'a central constriction of the swimbladder that delimits two subequal chambers', while Encheliophis species share a specialization of the swimbladder consisting of 'the presence of a thin, membranous, posterior terminal bulb', and the presence of some 'anterior dorsal pterygiophores that do not support fin rays'. On this basis, these authors reassigned three species from the genus Carapus to the genus Encheliophis: Encheliophis boraborensis (Kaup 1856) (formerly Carapus parvipinnis), Encheliophis homei (Richardson 1844) (formerly Carapus homei) and Encheliophis dubius (Putman 1874) (formerly Carapus dubius).

Yet several cephalic morphological features of Encheliophis gracilis on the one hand, and of Encheliophis boraborensis, 
Table 1 Diet of different Carapini species

\begin{tabular}{|c|c|c|}
\hline Species & Diet & Reference \\
\hline Carapus boraborensis & $\begin{array}{l}\text { Shrimps } \\
\text { Juvenile carapids } \\
\text { Fish }\end{array}$ & Van Den Spiegel and Jangoux (1989), Vandewalle et al. (1998) \\
\hline Carapus homei & Shrimps & $\begin{array}{l}\text { Smith (1964), Munro (1967), Branch (1969), Smith and Tyler (1969), Trott (1970, 1981), } \\
\text { Trott and Trott (1972), Van Den Spiegel and Jangoux (1989), Vandewalle et al. (1998) }\end{array}$ \\
\hline & $\begin{array}{l}\text { Juvenile carapids } \\
\text { Fish }\end{array}$ & \\
\hline Carapus acus & Crustacea & Arnold (1956) \\
\hline Carapus dubius & Decapods & Trott (1970) \\
\hline Carapus mourlani & $\begin{array}{l}\text { Shrimps } \\
\text { Fish } \\
\text { Juvenile carapids } \\
\text { Decapods } \\
\text { Annelids }\end{array}$ & Branch (1969), Meyer-Rochow (1979) \\
\hline Carapus bermudensis & $\begin{array}{l}\text { Juvenile carapids } \\
\text { Copepods } \\
\text { Isopods } \\
\text { Amphipods } \\
\text { Annelids } \\
\text { Stomatopods }\end{array}$ & $\begin{array}{l}\text { Smith and Tyler (1969), Trott (1970), Smith et al. (1981) } \\
\text { Govoni et al. (1984) }\end{array}$ \\
\hline Encheliophis gracilis & Holothuroids & $\begin{array}{l}\text { Strasburg (1961), Smith (1964), Branch (1969), Trott (1970, 1981), Trott and Trott (1972), } \\
\text { Van Den Spiegel and Jangoux (1989) }\end{array}$ \\
\hline Encheliophis vermicularis & Holothuroids & Smith (1955), Murdy and Cowan (1980), Trott (1981) \\
\hline Encheliophis sagamianus & Holothuroids & Trott (1981) \\
\hline Onuxodonsp. & $\begin{array}{l}\text { Crustacea } \\
\text { Annelids }\end{array}$ & Trott and Trott (1972), Parmentier et al. (2000) \\
\hline
\end{tabular}

Encheliophis homei, and Carapus acus on the other (Smith 1955; Arnold 1956; Munro 1967; Trott 1970; Cohen and Nielsen 1978; Williams 1984; Shen and Yeh 1987; Parmentier et al. 1998; Vandewalle et al. 1998) suggest that the latter three species form a fairly homogeneous group. Among the Carapini certain species appear to be parasitic, feeding on the internal tissues of their holothurian hosts, while others are considered commensal because their diet is not composed of host tissues (Table 1).

Some authors (Block et al. 1991; Motta and Kotrschal 1992; Norton et al. 1995) suggest an ecomorphological approach may shed light on connections between the morphology of organisms and their lifestyle, because it brings together data related to the optimization of the form-function complex in a given niche (e.g. Barel 1983; Kotrschal 1989; Sanderson 1990; Motta and Kotrschal 1992; Turingan 1994; Westneat 1995; Wainwright 1998). An ecomorphological approach could reinforce phylogenetic studies because various environmental factors may generate evolutionary features (Liem 1989; Lang 1990; Westneat 1995; Galis 1996) and could provide information on the relationship of several features to avoid weighting bias and to estimate the evolution of the structure complex (Liem and Greenwood 1981; Felsenstein 1982; Lauder and Liem 1983; Lang 1990; Galis and Drucker 1996; Galis 1996).

\section{Materials and Methods}

To facilitate discussion of results and to avoid confusion, a comparison of the different assignments is given in Table 2 . The genus and species names used in the text, tables and figures are those proposed on the basis of this study.

Specimens of Carapus boraborensis (eight specimens, TL: 13-30 cm), C. homei (six specimens, TL: 8-17 cm), Encheliophis gracilis (five specimens, TL: $16-24 \mathrm{~cm}$ ) and Onuxodon fowleri (five specimens, TL: 6-9 cm) were collected from the Bismarck Sea (Papua New Guinea) and/or around Moorea (French Polynesia). Carapus acus specimens (six specimens, TL: 7$15 \mathrm{~cm}$ ) were from the Mediterranean Sea (Calvi, Corsica).

Exemplars of other species were gifts or loans from the following institutions: AMNH (American Museum of Natural History, New York), ANSP (Academy of Natural Sciences of Philadelphia), BPBM (Bishop Museum, Hawaii), CAS (California Academy of Sciences), GCRL (Gulf Coast Research Laboratory), LACM (Natural History Museum of Los Angeles County), SIO (Scripps Institution of Oceanography, California), UF (Florida State Museum at the University of Florida), USNM (National Museum of Natural History of the Smithsonian Institution, Washington), VIMS (Virginia Institute of Marine Sciences) and ZMUC (Zoologisk Museum, Denmark). 
Table 2 Table of the different assignments

\begin{tabular}{lll}
\hline Arnold (1956) & Markle and Olney (1990) & This study \\
\hline Carapus acus & Carapus acus & Carapus acus (Brunnich 1768) \\
Carapus bermudensis & Carapus bermudensis & Carapus bermudensis (Jones 1874) \\
Carapus mourlani & Carapus mourlani & Carapus mourlani (Petit 1934) \\
& Carapus sluiteri & Carapus sluiteri (Weber 1913) \\
Carapus parvipinnis & Encheliophis boraborensis & Carapus boraborensis (Kaup 1856) \\
Carapus homei & Encheliophis homei & Carapus homei (Richardson 1844) \\
Carapus dubius & Encheliophis dubius & Carapus dubius (Putnam 1874) \\
Encheliophis (jordanicus) gracilis & Encheliophis gracilis & Encheliophis gracilis (Bleeker 1856) \\
Encheliophis (jordanicus) sagamianus & Encheliophis sagamianus & Encheliophis sagamianus (Tanaka 1908) \\
& Encheliophis vermiops & Encheliophis vermiops (Markle and Olney 1990) \\
Encheliophis vermicularis & Encheliophis vermicularis & Encheliophis vermicularis (Muller 1842) \\
Carapus caninus & Onuxodon fowleri & Onuxodon fowleri (Smith 1955a) \\
Snyderidia canina & Snyderidia canina & Snyderidia canina (Gilbert 1905) \\
\hline
\end{tabular}

Table 3 Matrix of the different characters. Data of Carapus sluiteri and Encheliophis vermiops are not confirmed; their feature states do not depend on this work

\begin{tabular}{|c|c|c|c|c|c|c|c|c|c|c|c|c|c|c|c|c|c|c|c|c|c|c|c|c|c|c|c|c|c|c|c|c|c|c|c|c|c|c|c|}
\hline Character & 1 & 2 & 3 & 4 & 5 & 6 & 7 & 8 & 9 & 10 & 11 & 12 & 13 & 14 & 15 & 16 & 17 & 18 & 19 & 20 & 21 & 22 & 23 & 24 & 25 & 26 & 27 & 28 & 29 & 30 & 31 & 13 & 32 & 33 & 34 & 35 & 36 & 37 & 38 \\
\hline S. canina & 0 & 0 & 0 & 0 & 0 & 0 & 0 & 0 & 0 & 0 & 0 & 0 & 0 & 0 & 0 & 0 & 1 & 0 & 0 & 0 & 0 & 1 & 0 & 0 & 1 & 0 & 1 & 0 & 0 & 0 & & 0 & 0 & 0 & 0 & 0 & 0 & 0 & 0 \\
\hline O. fowleri & 0 & 1 & 0 & 1 & 0 & 0 & 0 & 0 & 0 & 0 & 0 & 1 & 0 & 0 & 1 & 0 & 0 & 0 & 0 & 0 & 0 & 1 & 1 & 0 & 0 & 0 & 0 & 1 & 0 & 0 & & 0 & 0 & 0 & 0 & 0 & 1 & 1 & 0 \\
\hline C. mourlani & 0 & 0 & 1 & 0 & 0 & 0 & 0 & 0 & 1 & 0 & 0 & 1 & 1 & 0 & 1 & 1 & 0 & 1 & 0 & 0 & 1 & 0 & 0 & 1 & 0 & 0 & 0 & 0 & 1 & 0 & & 0 & 0 & 1 & 0 & 1 & 0 & 1 & 0 \\
\hline C. bermudensis & 0 & 0 & 0 & 0 & 0 & 0 & 0 & 0 & 1 & 0 & 0 & 1 & 1 & 0 & 1 & 1 & 0 & 1 & 0 & 0 & 1 & 0 & 0 & 1 & 0 & 0 & 0 & 0 & 1 & 0 & & 0 & 0 & 1 & 0 & 1 & 0 & 1 & 0 \\
\hline C. acus & 0 & 0 & 0 & 0 & 0 & 0 & 0 & 0 & 1 & 0 & 0 & 1 & 1 & 0 & 1 & 1 & 0 & 1 & 0 & 0 & 1 & 0 & 0 & 1 & 0 & 0 & 0 & 0 & 1 & 0 & & 0 & 0 & 1 & 0 & 1 & 0 & 1 & 0 \\
\hline C. sluiteri & 0 & $?$ & $?$ & 0 & 0 & 0 & $?$ & $?$ & 1 & $?$ & $?$ & 1 & 1 & 0 & 1 & 1 & 0 & 1 & 0 & 0 & 1 & 0 & 0 & 1 & 0 & 0 & 0 & ? & ? & ? & & $?$ & $?$ & $?$ & $?$ & 1 & 0 & 1 & ? \\
\hline C. homei & 0 & 0 & 0 & 0 & 0 & 0 & 0 & 0 & 1 & 0 & 0 & 1 & 1 & 0 & 1 & 1 & 0 & 1 & 0 & 0 & 1 & 0 & 0 & 1 & 0 & 0 & 0 & 0 & 0 & 0 & & 0 & 0 & 1 & 0 & 0 & 0 & 1 & $\mathrm{c}$ \\
\hline C. boraborensis & 0 & 0 & 0 & 0 & 0 & 0 & 0 & 0 & 1 & 0 & 0 & 1 & 1 & 0 & 1 & 1 & 0 & 1 & 0 & 0 & 1 & 0 & 0 & 1 & 0 & 0 & 0 & 0 & 1 & 0 & & 0 & 0 & 1 & 0 & 0 & 0 & 1 & 4 \\
\hline C. dubius & 0 & 0 & 0 & 0 & 0 & 0 & 0 & 0 & 1 & 0 & 0 & 1 & 1 & 0 & 1 & 1 & 0 & 1 & 0 & 0 & 1 & 0 & 0 & 1 & 0 & 0 & 0 & 0 & 1 & 0 & & 0 & 0 & 1 & 0 & 0 & 0 & 1 & C \\
\hline E. vermicularis & 1 & 0 & 1 & 0 & 1 & 1 & 1 & 1 & 1 & 1 & 1 & 1 & 1 & 1 & 1 & 1 & 0 & 1 & 1 & 0 & 0 & 0 & 0 & 0 & 0 & 1 & 0 & 1 & 0 & 0 & & 0 & 0 & 1 & 0 & 0 & 0 & 1 & T. \\
\hline E. gracilis & 1 & 0 & 1 & 0 & 1 & 1 & 1 & 1 & 1 & 1 & 1 & 1 & 1 & 1 & 1 & 1 & 0 & 1 & 1 & 1 & 0 & 0 & 0 & 0 & 0 & 1 & 0 & 1 & 0 & 1 & & 1 & 1 & 1 & 0 & 0 & 0 & 1 & 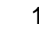 \\
\hline E. sagamianus & 1 & 0 & 0 & 0 & 1 & 1 & 1 & 1 & 1 & 1 & 0 & 1 & 1 & 1 & 1 & 1 & 0 & 1 & 1 & 0 & 0 & 0 & 0 & 0 & 0 & 1 & 0 & 0 & 1 & 0 & & 1 & 1 & 1 & 0 & 0 & 0 & 1 & 1 \\
\hline E. vermiops & 1 & $?$ & $?$ & 0 & 1 & 1 & $?$ & $?$ & 1 & $?$ & $?$ & 1 & 1 & 1 & 1 & 1 & 0 & 1 & 1 & $?$ & 0 & 0 & 0 & 0 & 0 & 1 & 0 & $?$ & ? & $?$ & & $?$ & $?$ & $?$ & $?$ & 0 & 0 & 1 & 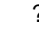 \\
\hline
\end{tabular}

Encheliophis vermicularis: Maitre Islet, New Caledonia: VIMS 09600 (2); Philippines, Indo-West Pacific: CAS 127136 (1), CAS 127133 (1), AMNH 13871 (1), USNM 140946 (5).

Encheliophis sagamianus: Hokkaido Island, Japan: AMNH 13034 (1).

Carapus dubius: Costa Rica: LACM 32479-3 (1); Mexico, Pacific: CAS 102506 (2); Colombia, South America: AMNH 16090 (1); Panama, Pacific Ocean: UF 219384 (1); unknown locality: SI066-492 (1), SI071-53 (1 cleared and stained).

Carapus bermudensis: Panama, GCRL 65971 (1 cleared and stained), GCRL 140921 (1); Antigua, Caribbean Sea: CAS 132030 (1); Bahamas, West Indies: AMNH 2357 (2), ANSP 113560; North Carolina, Atlantic Ocean: UF 40776 (1).

Carapus mourlani: USA: USNM 140946 (4); Cannonier Point, Mauritius: ZMUC-P 771136 (1); Papua New Guinea, Philippines: CAS 81397 (2); Hawaiian Islands: BPBM 12057 (2), 17821 (1); Philippines, Indo-West Pacific: ANSP 117717 (1).

Snyderidia canina: USA: USNM 215468 (1); Japan: University of Kyoto 9669 (1).
Carapus sluiteri and Encheliophis vermiops were not available, but they are given a hypothetical place in the cladogram on the basis of features reported by Markle and Olney (1990).

The fishes were dissected and examined with a Wild M10 (Leica Camera AG, Solms, Germany) binocular equipped with a camera lucida. Two E. boraborensis and two E. homei specimens were stained with Alizarin according to Taylor and Van Dyke (1985). Phylogenetic analysis of the species was done with PAUP 3.1.1 (Swofford 1993; Swofford and Begle 1993). The characters used were classified as present or absent and are numbered in parentheses in the text. As both the presence and linkage of a character can have an impact on the general organization of a functional complex (Vandewalle and Chardon 1981; Barel 1983; Parmentier et al. 2000), the matrix (Table 3) takes interdependent characters into account to avoid their overvaluation (Felsenstein 1982; Galis 1996).

As most characters of some Carapidae species have been presented by Vandewalle et al. (1998) or Parmentier et al. (1998, 2000), they are described only briefly in the following 

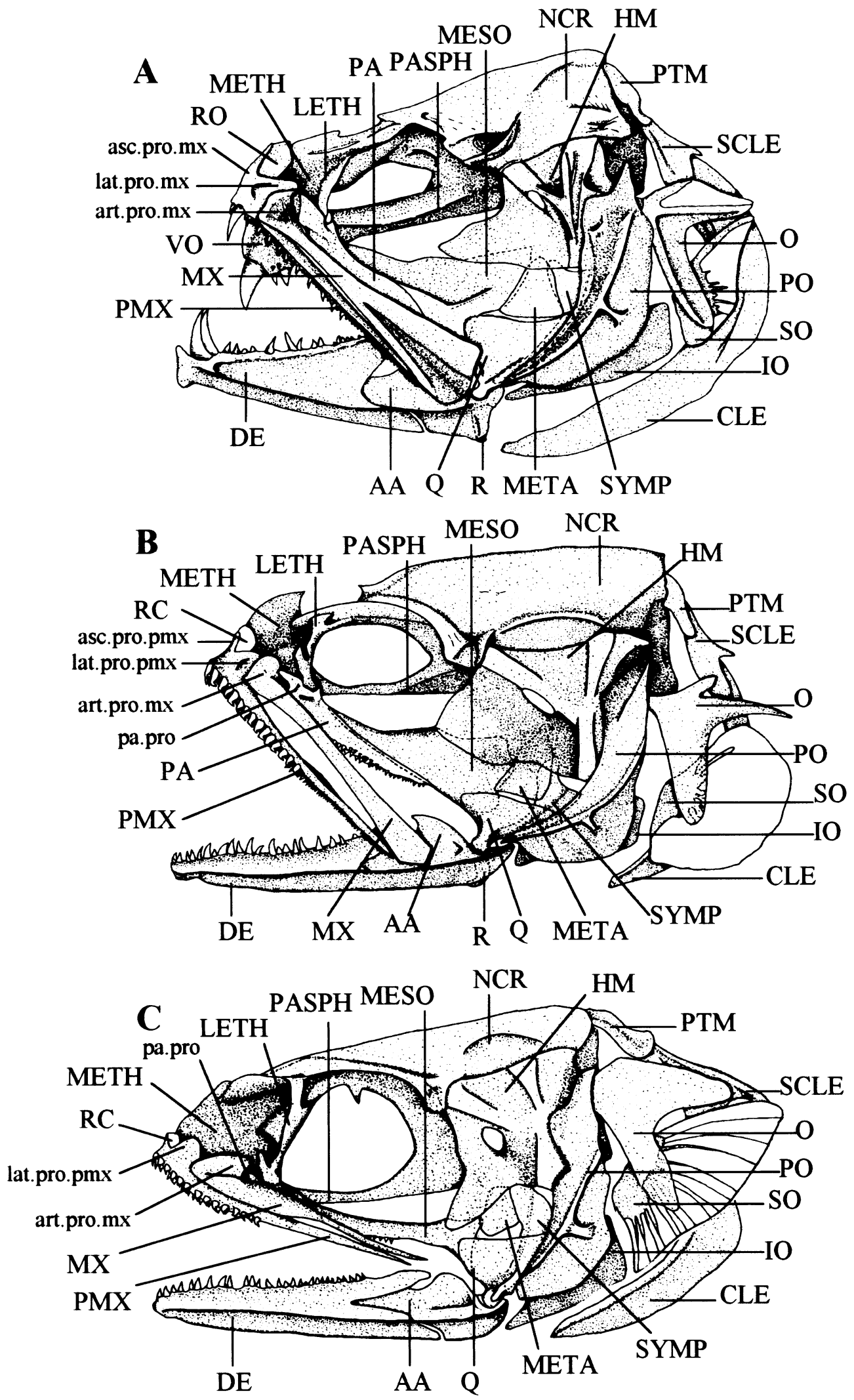

Fig. 1-Lateral view of the skull and associated bones. - A. In Snyderidia canina. - B. In Carapus bermudensis. -C. In Encheliophis sagamianus . 
text. Characters presented by other authors (Smith 1955; Arnold 1956; Munro 1967; Trott 1970; Cohen and Nielsen 1978; Williams 1984; Shen and Yeh 1987) are associated with the results.

\section{Results}

\section{Skeleton}

faws (Fig. 1). Only in Encheliophis gracilis, E. vermicularis and $E$. sagamianus are the upper jaws completely hidden by skin (1). At the front of the premaxillaries, ascending and lateral processes are clearly distinct in all Carapus species, E. sagamianus and Snyderidia canina. In Onuxodon fowleri, the ascending process is very reduced (2). The two processes are nearly parallel in E. gracilis and E. vermicularis (3). Onuxodon fowleri is the sole species to have a foramen in front of the premaxillary (4), serving to receive the large anterior teeth borne on the dentary. In E. gracilis, E. sagamianus and $E$. vermicularis, the premaxillary tapers posteriorly to a point (5); in the other species examined, it broadens into a plate approximately hiding the coronoid processes of the mandible. A ligament (Fig. 5) extending from the front of the premaxillary to the articulo-angular in nearly all the species is absent in E. gracilis, E. sagamianus and E. vermicularis (6). These three species additionally have maxillaries and premaxillaries that are interdependent, owing to the presence of short connective fibres (7), and their coronoid processes are relatively short (reaching only $16-18 \%$ of the length of the mandible, vs. $25-30 \%$ in the other species) (8).

Lateral ethmoid (Markle and Olney 1990). In Carapini species, the lateral ethmoid (Fig. 2) possesses a small lateral branch conferring a U-shape to the bone (9).

Opercular bones. In S. canina, O. fowleri and the Carapus species, the subopercle ends posteriorly with a strong ridge dorsally and small ridges below. In E. gracilis, E. sagamianus and $E$. vermicularis, it is extended by numerous long ossified expansions (10).

Branchial basket (Munro 1967; Williams 1984; Markle and Olney 1990; Vandewalle et al. 1998). Encheliophis gracilis and E. vermicularis have a reduced pharyngobranchial 2 and pharyngobranchial 4 is relatively better developed (11) (Fig. 3A). The interarcual element that links epibranchial 1 to pharyngobranchial 2 is cartilaginous and articulated with the distal end of epibranchial 1 in S. canina (Fig. 3B) but is bony and articulates with a process on epibranchial 1 in the other species (12). This element articulates very low on the first epibranchial in the Carapini only (13). A distinctive feature of E. gracilis, E. sagamianus and E. vermicularis is the loss of developed gill rakers (14). Three well-developed gill rakers are present on the first ceratobranchial in all other fishes of the family.

Vertebral column and unpaired fins (Markle and Olney 1990). Only S. canina has pleural ribs (15). In all Carapini, the first parapohysis (located on the third centrum) is greatly extended posteriorly and extends to below the fourth or fifth centrum (16). According to Markle and Olney (1990), Encheliophis species, C. homei, C. boraborensis and C. dubius are characterized by the lack of fin rays on some anterior dorsal pterygiophores. In two Alizarin-stained C. homei specimens, all the anterior pterygiophores supported reduced rays. In a similarly stained $C$. boraborensis specimen, only the first pterygiophore did not possess a ray. As the situation does not seem clear, this character is not included in the matrix.

\section{Dentition}

(Arnold 1953; Smith 1955; Munro 1967; Trott 1970; Williams 1984; Shen and Yeh 1987; Markle and Olney 1990; Parmentier et al. 1998, 2000; Vandewalle et al. 1998)

faws (Fig. 1, 4). Only in S. canina does the premaxillary bear an external row of straight, spaced, conical teeth (17). External cardiform teeth are a synapomorphy of the Carapini (18). Within the tribe, E. sagamianus, E. vermicularis and E. gracilis lack small conical teeth on the second half of the premaxillary (19); E. gracilis lacks teeth on the front of the premaxillary (20). The Carapus species show two or more enlarged teeth (21) in front.

In $O$. fowleri and S. canina, the premaxillary and dentary bear one or two large, well-developed fangs anteriorly. These teeth are absent in Carapus and Encheliophis species (22). In O. fowleri, fangs are followed by a well-marked diastema (23) on the dentary and the premaxillary. Posterior to the diastema, O. fowleri possesses several rows of small conical teeth situated on the front of the dentary. Carapus is distinguishable by the presence of small teeth externally bordered by larger, inward-curving teeth (24). Snyderidia canina, E. sagamianus, E. gracilis and E. vermicularis possess a single row of teeth on the dentary, but those of $S$. canina are clearly distinguishable by their larger size in the anterior region (25); in the three Encheliophis species, the anterior teeth are smaller and of uniform size (26).

Cohen and Nielsen (1978) place the Carapidae in the suborder Ophidioidei with the Ophidiidae. In the latter group, these author note the jaw teeth are granular, minute, densely distributed and rather blunt tipped except in one genus (Epetriodus sp.) in which they are needlelike. The plesiomorphic condition in the dentary should be small and conical teeth. Several conditions are derived from this state: (1) appearance of the fang-like teeth in Snyderidia sp., Onuxodon sp., Pyramodon sp. and Echiodon sp. (Cohen and Nielsen 1978; Williams 1983, 1984; Markle and Olney 1990) may be a family synapomorphy that is secondarily lost in the Carapini (22); (2) development of an external row of larger teeth in Carapus (24); (3) from the latter state and in relation to their mode of life, reduction of the dentition pattern in Encheliophis sp. with the loss of the small internal conical teeth (26). On the other hand, the dentary dentition 
C. acus

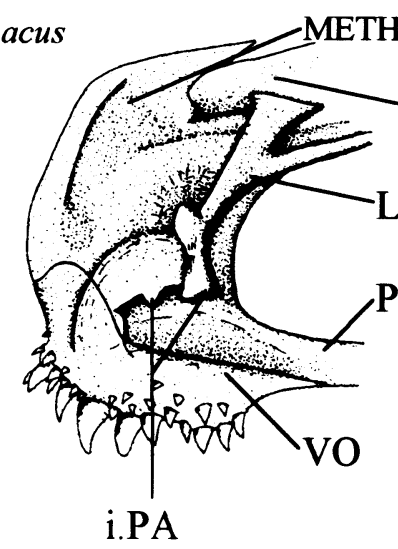

C. dubius

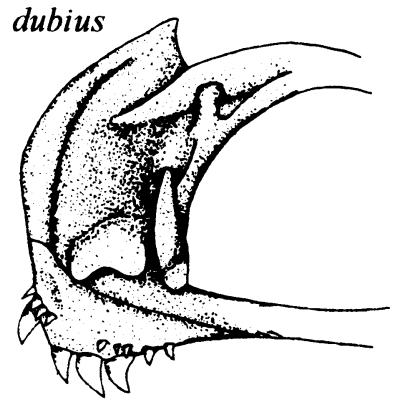

E. gracilis

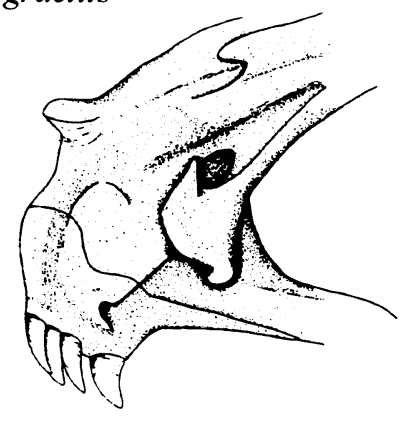

C. bermudensis

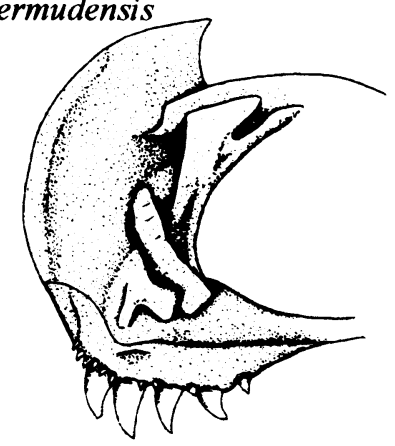

C. boraborensis

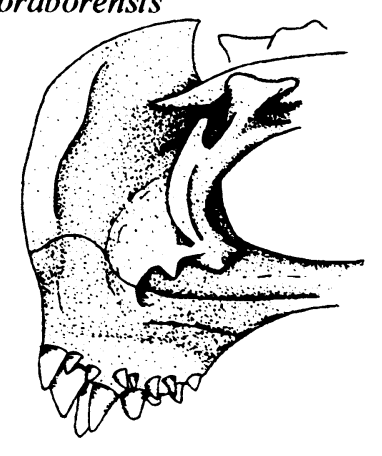

C. homei

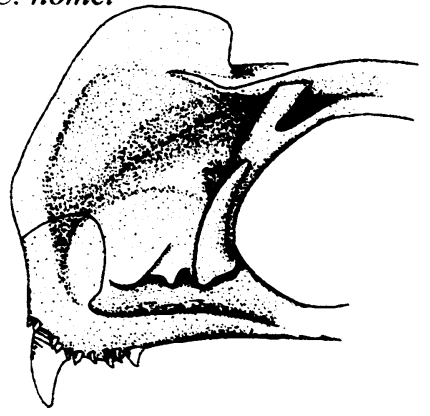

E. sagamianus

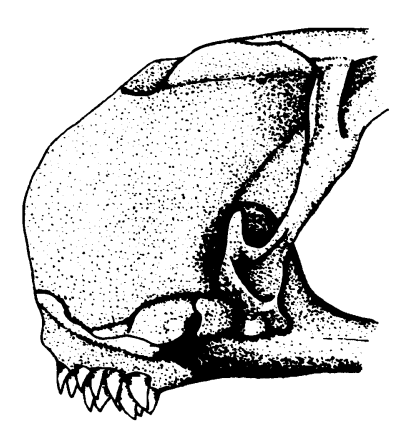

C. mourlani

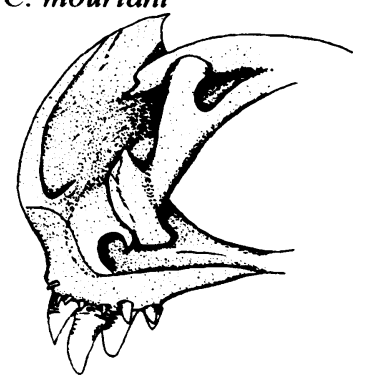

E. vermicularis

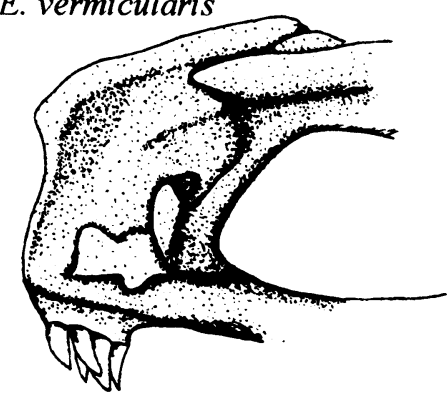

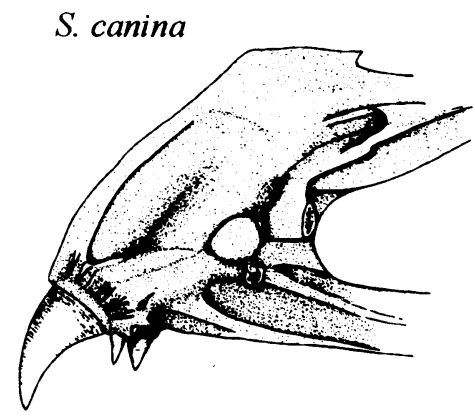

O. fowleri

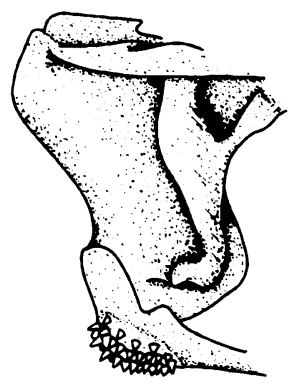

Fig. 2-Lateral view of the anterior part of the neurocranium in different Carapidae. 

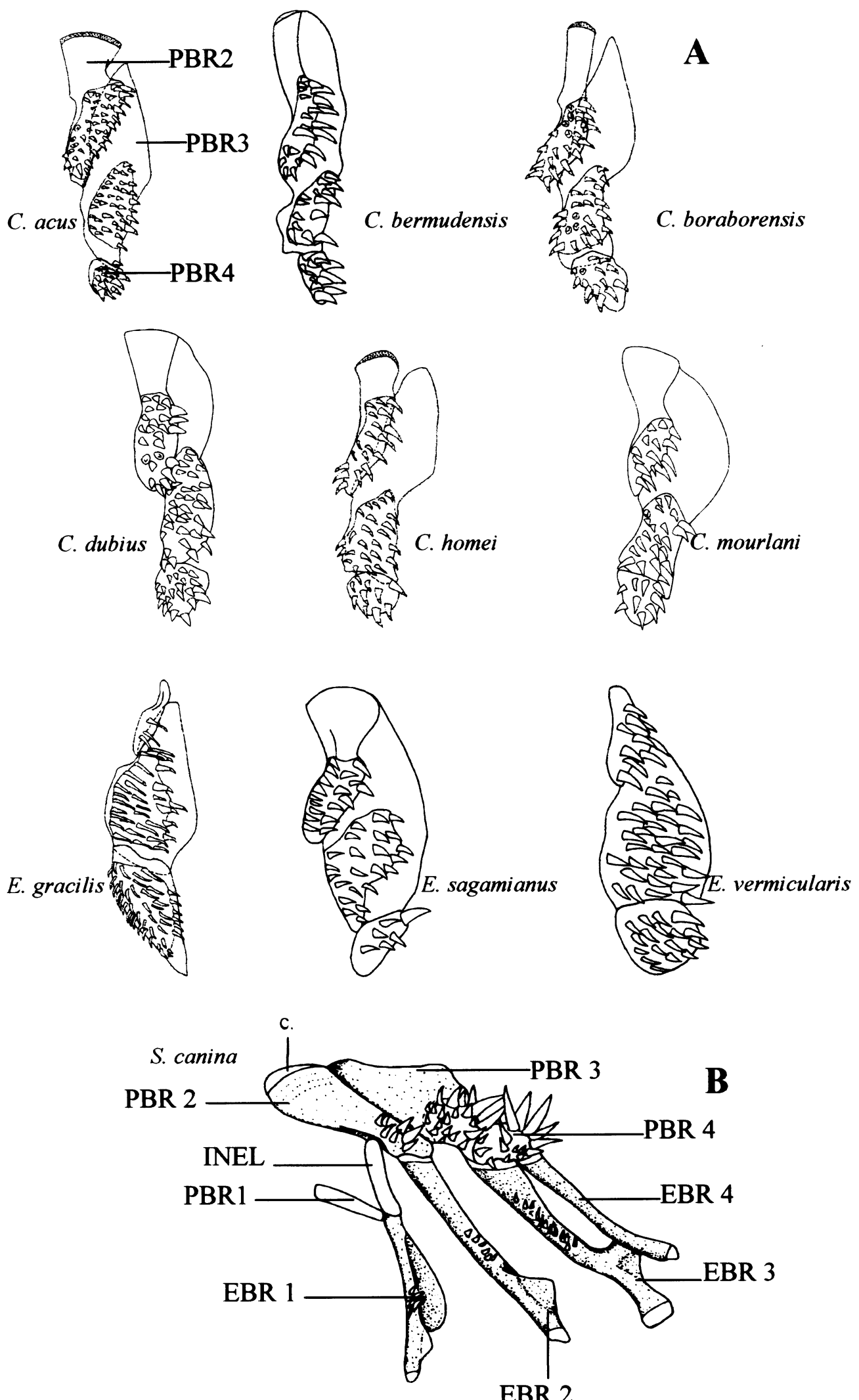

Fig. 3-Ventral view of the left upper pharyngeal jaws. - A. In different Carapini . - B. With the left epibranchials in Snyderidia canina. 

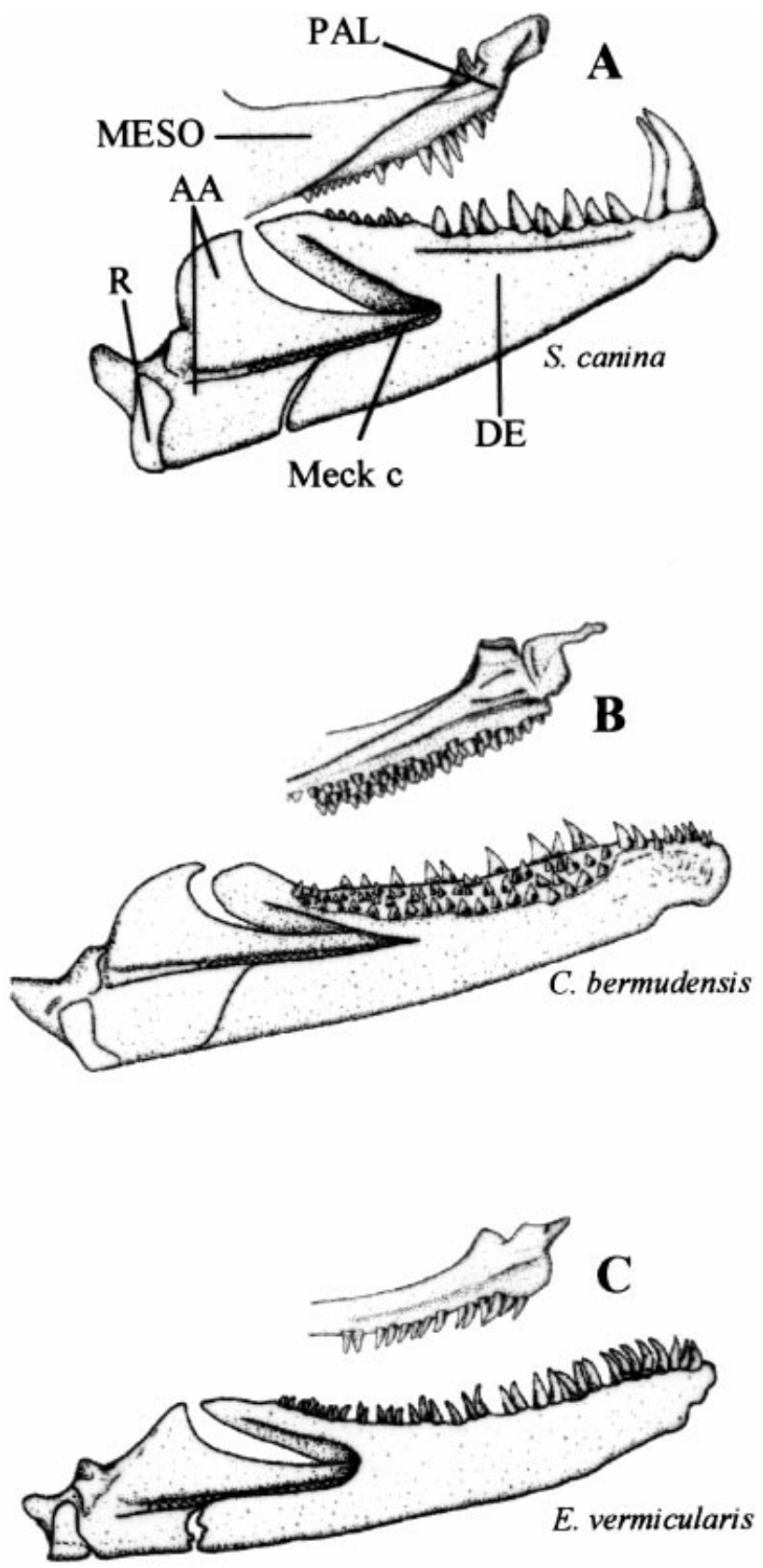

Fig. 4-Inner lateral view of the left palatine and mandible. -A. In Snyderidia canina. - B. In Carapus bermudensis.

-C. In Encheliophis vermicularis.

pattern of Snyderidia canina is easily distinguishable from the Carapini, i.e. fang-like teeth at the front followed by large teeth of different size (25), and constitutes a derived state different from the tribe Carapini.

Vomer (Fig. 2). The dentition of the vomer is quite complex and various. Snyderidia canina has a very prominent tooth (27) surrounded by smaller ones (Smith 1955). In the other species, there can be large conical teeth surrounded by smaller conical teeth or only the latter. As the polarity is ambiguous, the characters are not included in the matrix.

Palatine (Fig. 4). In the Carapidae, there is occlusion between the palatine teeth and those of the dentaries (except for the teeth inserted on the anterior part of the mandible): the morphology of the palatine teeth is thus considered linked to that of the dentary teeth facing them (see characters $24,25,26)$.

Branchial basket. The basibranchial bears small conical teeth in all species except $O$. fowleri, E. gracilis and $E$. vermicularis. Unlike Markle and Olney (1990), these teeth were observed in E. sagamianus and E. boraborensis. As Cohen and Nielsen (1978) observed small teeth in most genera of Ophidioidei, the loss of this character (28) is hypothesized to have been independently derived. Unlike $S$. canina and O. fowleri, Carapini possess teeth on the third hypobranchials, this character (29) being reversed in C. homei, E. gracilis and E. vermicularis.

On the other hand, E. gracilis is the only species to bear cardiform teeth on the fifth ceratobranchials (30).

\section{Musculature}

Adductor mandibulae (Fig. 5). The organization of the A1 adductor mandibulae bundle is unique in E. gracilis, E. sagamianus and E. vermicularis: $\mathrm{A} 1 \alpha$ inserts directly on the maxillary instead of on the maxillo-mandibular ligament as in the other species. This character is thus linked to the absence of the ligament in the latter species - character (6). The A1 $\beta$ insertion extends onto the external anterior face of the maxillary in all three Encheliophis species (31) instead of being focused on the inner face as in the other species examined.

Branchial basket (Fig. 6). In E. gracilis, E. sagamianus and E. vermicularis, some bundles of adductor 5 insert on both the third and fourth epibranchials (32). In the other species, they insert only on the fourth. The Carapini are distinguishable from $O$. fowleri and $S$. canina by the presence and insertion of four recti dorsales muscles (33); the first connects the 2nd pharyngobranchial and the interarcual element, the second connects the interarcual element and the 2nd epibranchial, the third connects the 2nd and 3rd epibranchials, and the fourth connects the $3 \mathrm{rd}$ and 4 th epibranchials. The second rectus dorsalis is present in $S$. canina but its posterior insertion is focused in the distal part of the 3rd epibranchial; in the Carapini, it spreads along this bone. Onuxodon fowleri has only the fourth rectus dorsalis. All the species except $S$. canina possess a first obliquus dorsalis between the 2 nd pharyngobranchial and the interarcual element (12). The absence of this character in S. canina is linked to the short length and the position of the interarcual element. 
A

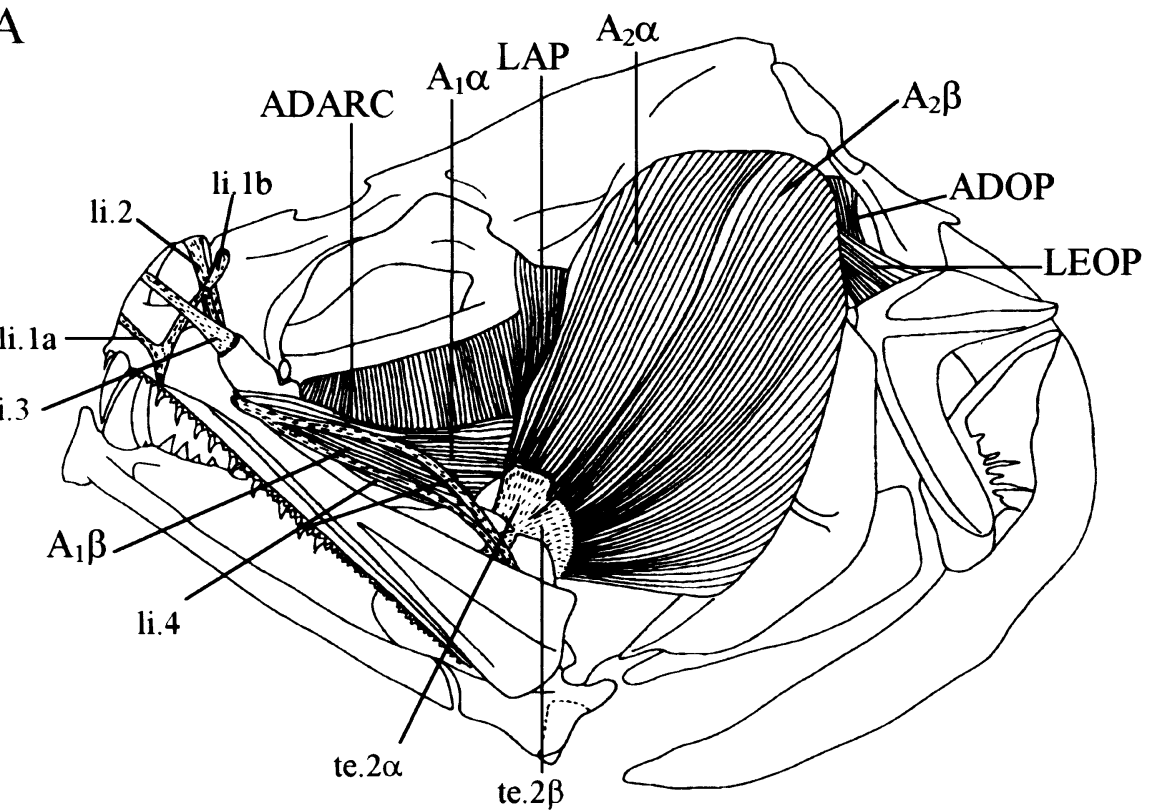

B
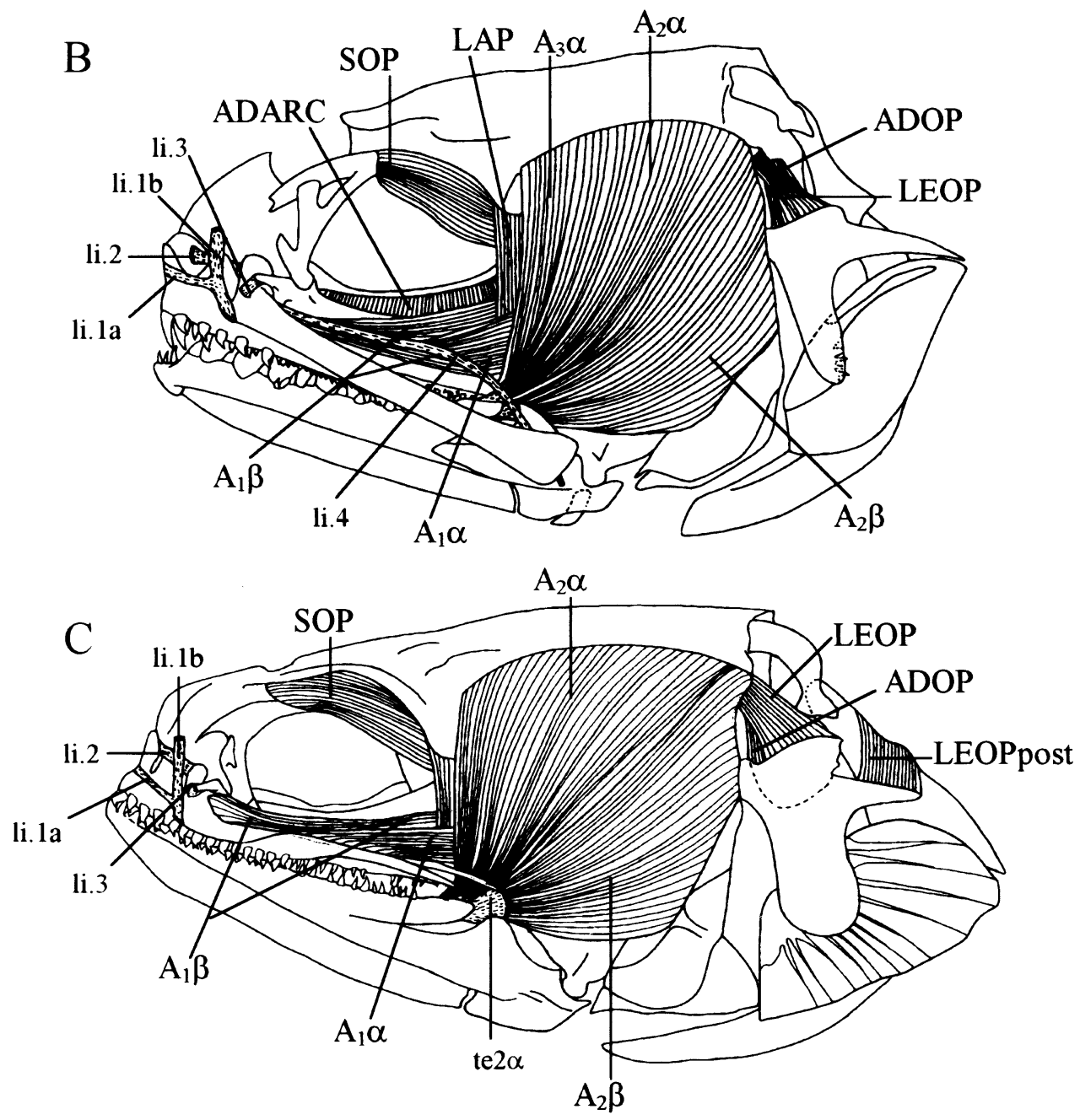

Fig. 5-Lateral view of the superficial muscles. - A. In Snyderidia canina. —-B. In Carapus mourlani. — C. In Encheliophis vermicularis. 

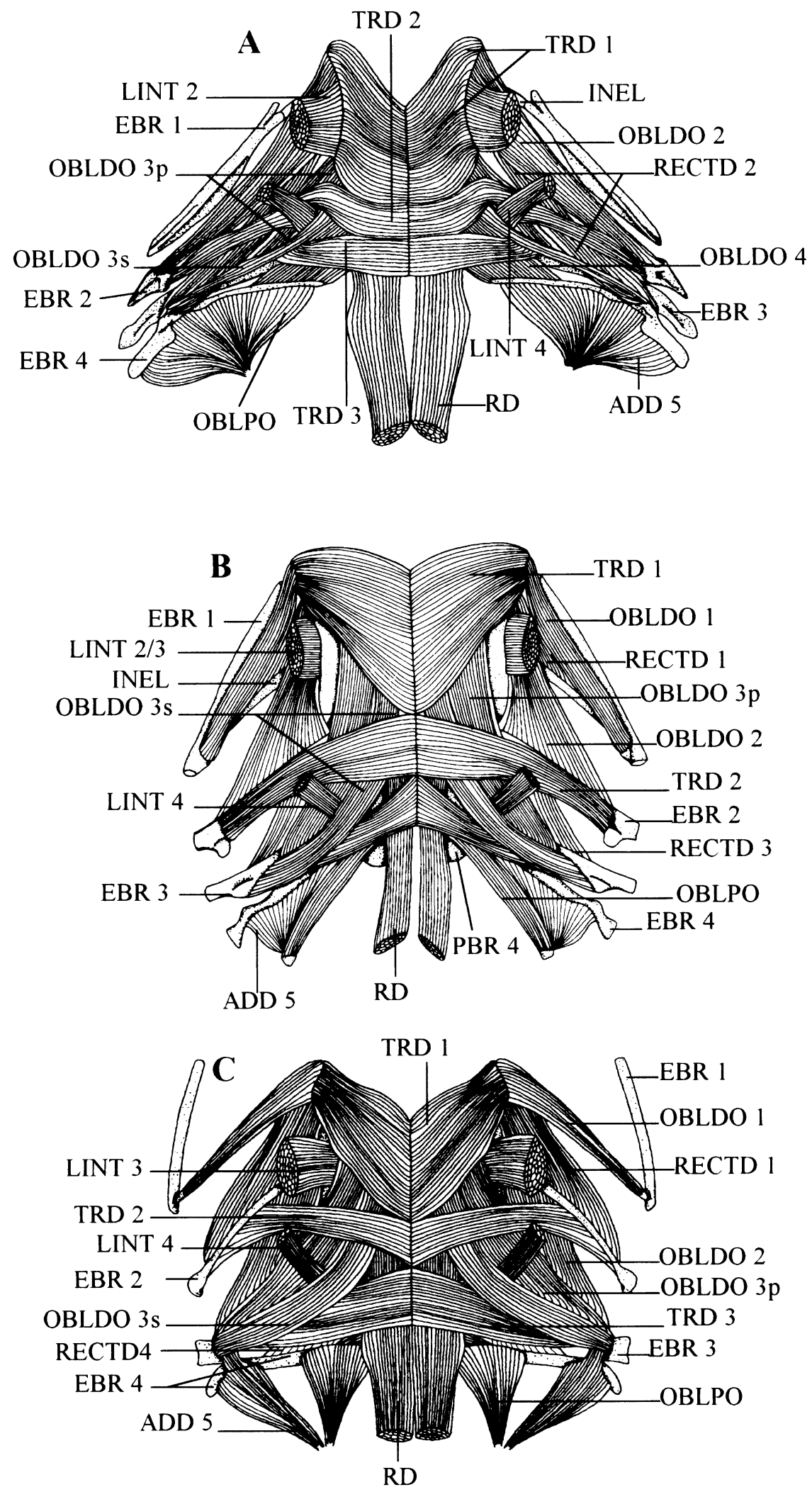

Fig. 6-Dorsal view of upper pharyngeal jaw muscles. - A. In Snyderidia canina. - B. In Carapus bermudensis. - C. In Encheliophis vermicularis. 
Table 4 Hosts of different Carapini species

\begin{tabular}{|c|c|c|}
\hline Species & Host & Reference \\
\hline Carapus boraborensis & Holothuroids & $\begin{array}{l}\text { Smith (1964), Munro (1967), Trott (1981) -Van Den Spiegel and Jangoux (1989), Trott (1970), } \\
\text { Markle and Olney (1990) }\end{array}$ \\
\hline \multirow[t]{2}{*}{ Carapus homei } & Holothuroids & $\begin{array}{l}\text { Smith (1964), Branch (1969), Trott }(1970,1981), \text { Smith and Tyler (1969), Trott and Garth (1970), } \\
\text { Markle and Olney (1990) }\end{array}$ \\
\hline & Bivalvia & Van Den Spiegel and Jangoux (1989), Munro (1967) \\
\hline Carapus acus & Holothuroids & Emery (1880), Gustato et al. (1979), Trott (1981), Arnold $(1953,1956)$ \\
\hline Carapus dubius & Bivalvia & Trott (1981), Castro-Aguirre et al. (1996), Markle and Olney (1990), Paredes-Rios and Balart (1999) \\
\hline Carapus mourlani & $\begin{array}{l}\text { Holothuroids } \\
\text { Asteroids }\end{array}$ & $\begin{array}{l}\text { Smith (1964), Branch (1969), Trott (1970), Markle and Olney (1990) } \\
\text { Smith (1964), Trott }(1970,1981), \text { Cheney (1973), Meyer-Rochow (1979), Markle and Olney (1990) }\end{array}$ \\
\hline Carapus bermudensis & Holothuroids & $\begin{array}{l}\text { Smith and Tyler (1969), Van Meter and Ache (1974), Govoni et al. (1984), Smith et al. (1981), } \\
\text { Tyler et al. (1992) }\end{array}$ \\
\hline Encheliophis gracilis & Holothuroids & $\begin{array}{l}\text { Smith (1964), Branch (1969), Munro (1967), Trott (1970), Trott and Garth (1970), Van Den } \\
\text { Spiegel and Jangoux (1989), Markle and Olney (1990) }\end{array}$ \\
\hline Encheliophis vermicularis & Holothuroids & Smith (1955), Murdy and Cowan (1980), Trott (1981) \\
\hline Encheliophis sagamianus & Holothuroids & Trott (1970, 1981), Murdy and Cowan (1980) \\
\hline \multirow[t]{2}{*}{ Onuxodon sp. } & Bivalvia & Tyler (1970), Trott and Trott (1972), Markle and Olney (1990) \\
\hline & Holothuroids & Parmentier et al. (2000) \\
\hline
\end{tabular}

\section{Swimbladder}

(Courtenay and McKittrick 1970; Williams 1984; Markle and Olney 1990) Primary sound-producing muscles (34) like those described by Courtenay and McKittrick (1970) in $C$. bermudensis and two Onuxodon species are present in all species studied here. The central constriction of the swimbladder (35) described by Markle and Olney (1990) in C. acus, C. bermudensis and C. mourlani is confirmed. Only O. fowleri possesses a rockerbone in front of the swimbladder (36).

The character 'presence of a thin, membranous, posterior terminal bulb on the swimbladder', proposed by Markle and Olney (1990) as characteristic of Encheliophis spp., C. boraborensis, C. homei and C. dubius, was not taken into account. We were unable to distinguish the latter species from C. mourlani, C. bermudensis and C. acus on this basis.

\section{Ethology}

(Tables 1, 4) Snyderidia canina swims freely; Carapus, Onuxodon and Encheliophis are commensal or parasitic with different invertebrate hosts (37). Adults of E. gracilis, E. vermicularis and E. sagamianus are parasitic, feeding exclusively on the internal tissues of their hosts (38).

\section{Discussion}

The tree shown in Fig. 7 was drawn on the basis of an exhaustive analysis of the above-mentioned characters. Clearly, C. boraborensis, C. homei and C. dubius are members of the Carapus clade and are reassigned to this genus with the respective binomial designations Carapus homei (Richardson 1884), Carapus dubius (Putnam 1874) and, as discussed by Markle and Olney (1990), Carapus boraborensis (Kaup 1856).

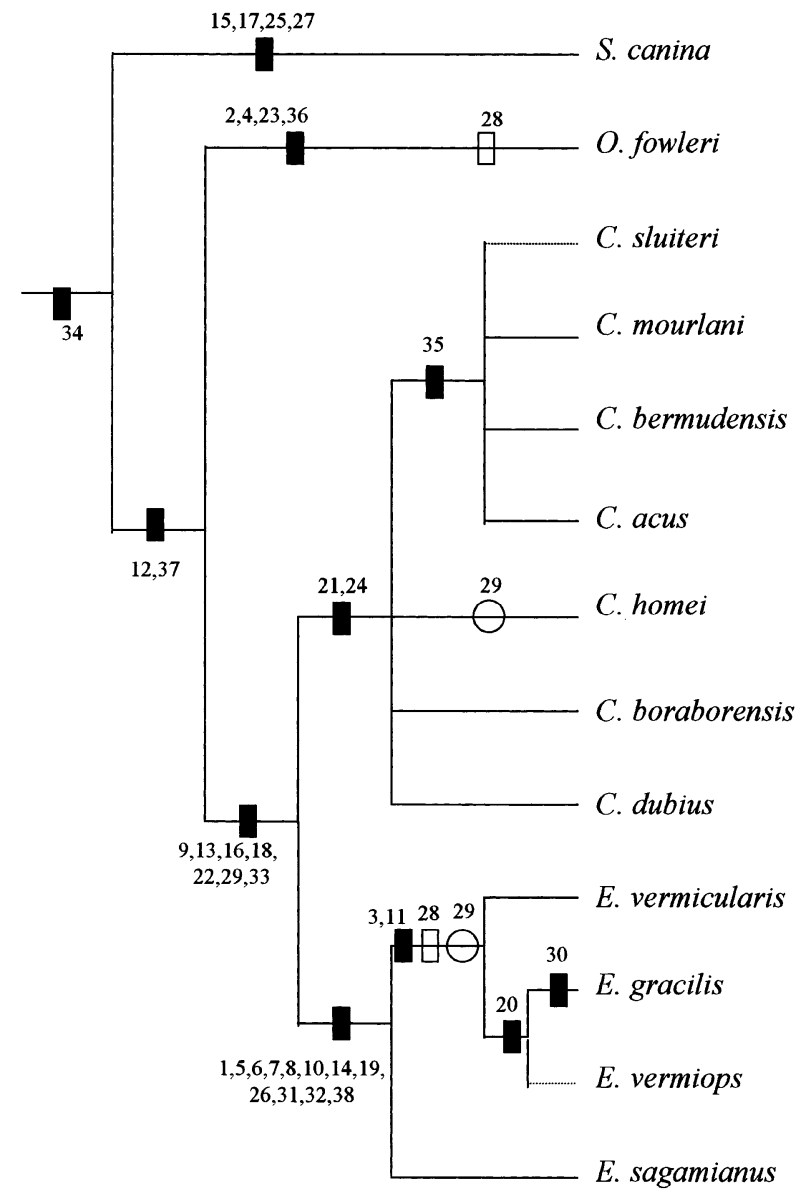

Fig. 7-Cladogram of relationships of species in Carapini. Dark rectangles indicate uniquely derived nonhomoplastic characters, open rectangles indicate homoplasies and open circles indicate reversal. Dotted lines indicate that these species were placed hypothetically, the feature number being insufficient and related data not confirmed. 
The cladogram further shows the following:

1 Two features of the jaw dentition are indicative of the monophyly of the genus Carapus: the presence of enlarged teeth at the front of the premaxillaries (21) and, on the dentary, an external row of conical teeth, larger than those of the inner rows (24).

2 Character (35), i.e. the central constriction of the swimbladder first described by Markle and Olney (1990) as evidence of the monophyly of the Carapus genus Carapus, remains valid for the subset C. mourlani, C. bermudensis, $C$. acus but does not apply to the three transferred species. On this basis, one might divide Carapus into two subgenera. 3 Eleven features $(1,5,6,7,8,10,14,19,26,31$ and 32) are shared by all Encheliophis species: maxillaries hidden by skin (1) and reduction of the three gill rakers of the first arch (14) have already been identified as synapomorphies of the genus by Smith (1955), Munro (1967), Williams (1984) and Shen and Yeh (1987). A third character accepted by these authors is the restricted mobility of the upper jaws. The absence of movement between the maxillary and premaxillary and the rest of the head is linked to features 6 , 7 and 31 (Parmentier et al. 1998).

4 The distinction between commensal species (Carapus) and the further derived parasitic species (Encheliophis) confirms the link between lifestyle constraints and morphological features (Mayr 1981; Bock 1989; Liem 1989; Lang 1990; Westneat 1995; Galis 1996). Like all fish feeding on mobile prey, the Carapus species, which hunt in their aquatic environment, have retained an apparatus enabling them to grasp and/or suck up and retain hard and elusive prey: strong jaws, a considerable dentition, a slight protraction of the upper jaws, and the capacity to open the mouth wide (Parmentier et al. 1998, 2000). These characters are also present in other Carapidae with a similar diet. On the other hand, Encheliophis species feed on the soft internal tissues of their hosts. The endoparasitic lifestyle does not impose the same constraints as food intake in open water. This situation is reflected in their morphology: the upper and lower jaws are less robust, with shorter coronoid processes on the mandible (5 and 8 ), the dentition is weakly developed (19, $20,21,24,26)$, and the upper jaws lack mobility $(6,7$, and $31)$. On the other hand, a prolonged stay within the host imposes another constraint: these fish must have an efficient respiratory system: the subopercle is reinforced by bony extensions that should improve the opercular pump required for respiration (Vandewalle and Chardon 1981). This evolutionary scheme is in keeping with Trott's hypothesis (1970) that Encheliophis may have evolved from a Carapus-like ancestor. First the host would have been used as shelter, later as a food supply; once this change occurred, the buccal structures would have adapted in response to the new lifestyle.

On the basis of the present data, we propose to change the diagnosis of these genera as follows:

Carapus Rafinesque: Carapidae species lacking pelvic fins, a rockerbone, fangs and a diastema on the premaxillary and dentary. Carapidae bearing cardiform teeth on the premaxillary, two to three enlarged teeth anteriorly on this bone, and at least two rows of small conical teeth over the entire length of the premaxillary; bearing an external row of conical teeth and several rows of internal smaller conical teeth on the dentary.

Encheliophis Müller: Carapidae species lacking pelvic fins, a rockerbone, fangs and a diastema on the premaxillary and dentary; also lacking small conical teeth on the posterior part of the premaxillary, three well-developed gill rakers on the first ceratobranchial, and a maxillo-mandibular ligament. Carapidae possessing cardiform teeth on the premaxillary and small conical teeth only on its anterior part (or no conical teeth at all), a single row of small, evenly spaced teeth on the dentary, a maxillary ending in a bump, and maxillary and premaxillary bound by skin to the head.

Although few characters have been determined for $C$. sluiteri and E. vermiops, their generic membership can be confirmed on the basis of these diagnostic criteria.

\section{Acknowledgements}

We thank C. Michel and S. Houbart (Aquarium, Liège), J. M. Olin and G. Seghers (Laing Island Biological Station, Papua New Guinea), and Dr D. Bay (STARESO, Calvi, France) for providing specimens. We are particularly grateful to the following individuals for the gift and/or loan of specimens: B. A. Brown and C. L. Smith (AMNH); W. G. Saul (ANSP); A. Suzumoto and J. E. Randall (BPBM); D. Catania and T. Iwamoto (CAS); M. O'Connell and S. G. Poss (GCRL); Y. Machida (Kyoto University of); R. F. Feeney (LACM); R. Rosenblatt (SIO); G. H. Burgess and R. H. Robins (UF); J. T. Williams and S. L. Jewett (USNM); J. E. Olney (VIMS); C. Nielsen (ZMUC). We are grateful to Dr J. T. Williams for its constructive comments on this manuscript. Mrs K. Broman provided linguistic assistance. This work is supported by grant no. 2.4560.96 from the Belgian 'Fonds National de la Recherche Scientifique' (National Fund for Scientific Research).

\section{List of abbreviations}

$\mathbf{A}_{1} \alpha$ : adductor mandibulae $\mathrm{A}_{1} \alpha$ $\mathbf{A}_{1} \beta$ : adductor mandibulae $\mathrm{A}_{1} \beta$ $\mathbf{A}_{2} \alpha$ : adductor mandibulae $\mathrm{A}_{2} \alpha$ $\mathbf{A}_{2} \beta$ : adductor mandibulae $\mathrm{A}_{2} \beta$ $\mathbf{A}_{3} \alpha$ : adductor mandibulae $\mathrm{A}_{3} \alpha$ AA: articuloangular

ADARC: arcus palatini adductor

ADD 5: adductor branchialis 5

ADOP: adductor operculi

art.pro.mx: articular process of the maxillary asc.pro.pmx: ascending process of the premaxillary c. cartilage 
CLE: cleithrum

DE: dentary

EBR: epibranchial

HM: hyomandibular

INEL: interarcual element

IO: interoperculum

i.PA: insertion of the palatine

lat.pro.pmx: lateral process of the premaxillary

LAP: levator arcus palatini

LEOP: levator operculi

LETH: lateral ethmoid

LEXT: levator externus

li. ligaments

LINT: levator internus

Meck c: Meckel's cartilage

MESO: mesopterygoid

META: metapterygoid

METH: mesethmoid

MX: maxillary

NCR: neurocranium

O: operculum

OBLDO: obliquus dorsalis

OBLDO 3 s: obliquus dorsalis 3 superficialis

OBLDO3 p: obliquus dorsalis 3 profondis

OBLPO: obliquus posterior

PA: palatine

PASPH: parasphenoid

PBR: pharyngobranchial

PMX: premaxillary

PO: preoperculum

PTM: post-temporal

Q: quadrate

R: retroarticular

RC: rostral cartilage

RD: retractor dorsalis

RECDT: rectus dorsalis

RO: rostral bone

SCLE: supracleithrum

SO: suboperculum

SOP: primary sound-producing muscle

SYMP: symplectic

te: tendon

TRD 1: tranvs. dorsalis anterior

TRD 2: tranvs. dorsalis centralis

TRD 3: tranvs. dorsalis posterior

\section{References}

Arnold, D. C. 1953. Observation on Carapus acus (Brünnich) (Jugulares, Carapidae). - Pubblicazioni Della Stazione Zoologica Di Napoli 24: 152-166.

Arnold, D. C. 1956. A systematic revision of the fishes of the teleost family Carapidae (Percomorphi, Blennioidea), with description of two new species. - Bulletin of the British Museum (Natural History), Zoology 4: 247-307.

Barel, C. D. N. 1983. Towards a constructional morphology of cichlid fishes (Teleostei, Perciformes). - Netherlands fournal of Zoology 33: 357-424.

Block, W. M., Brennan, L. A. and Gutierrez, R. J. 1991. Ecomorphological relationships of a guild of ground-foraging birds in northern California, USA. - Oecologia 87: 449-458.

Bock, W. J. 1989. From biologische anatomie to ecomorphology. Netherlands Fournal of Zoology 40: 254-277.

Branch, J. B. 1969. Observations on the ecology and behaviour of Guam pearlfishes (Carapidae). - Micronesica 24: 274.

Castro-Aguirre, J. L., Garcia-Dominguez, F. and Balart, E. F. 1996. Nuevos hospederos y datos morfométricos de Encheliophis dubius (Ophidiiformes: Carapidae) en el Golfo de California, México). - Revista de Biologia Tropical 44: 753-756.

Cheney, D. P. 1973. Pearlfish (Carapidae) in Acanthaster planci (L.) - Micronesica 9: 159.

Cohen, D. M. and Nielsen, J. G. 1978. Guide to identification of genera of the fish order Ophidiiformes with a tentative classification of the order. - NOAA Technical Report NMFS 417: 1-72.

Courtenay, W. R. and McKittrick, F. A. 1970. Sound-producing mechanisms in carapid fishes, with notes on phylogenetic implications. - Marine Biology 7: 131-137.

Emery, C. 1880. Le specie del genere Fierasfer nel golfo di Napoli e regione limitrofe. - Fauna und Flora Des Golfes Von Neapel 2: $1-76$.

Felsenstein, J. 1982. Numerical method for inferring evolutionary trees. - Quarterly Review of Biology 57: 379-404.

Galis, F. 1996. The application of functional morphology to evolutionary studies. - Trends in Ecology and Evolution 1: 124-129.

Galis, F. and Drucker, E. G. 1996. Pharyngeal biting mechanics in centrarchid and cichlid fishes: insights into a key evolutionary innovation. - fournal of Evolutionary Biology 9: 641-670.

Govoni, J. J., Olney, J. E., Markle, D. F. and Curtsinger, W. R. 1984. Observations on structure and evaluation of possible functions of the vexillum in larval Carapidae (Ophidiiformes). Bulletin of Marine Science 34: 60-70.

Gustato, G., Villari, A. and Villani, G. 1979. Ulteriori dati sul comportamento di Carapus acus (Gadiformes, Ophidiodei). Bollettino Societa Natura Listi Di Napoli 88: 535-547.

Kotrschal, K. 1989. Trophic ecomorphology in eastern Pacific blennioid fishes: character transformation of oral jaws and associated change of their biological roles. - Environmental Biology of Fishes 24: 199-218.

Lang, M. 1990. Cladistic as a tool for morphologists. - Netherlands Fournal of Zoology 40: 386-402.

Lauder, G. V. and Liem, K. F. 1983. The evolution and interrelationships of the Actinopterygian fishes. - Bulletin of the Museum of Comparative Zoology 150: 95-197.

Liem, K. F. 1989. Functional morphology and phylogenetic testing within the framework of Symecomorphosis. - Acta Morphologica 27: 119-131.

Liem, K. F. and Greenwood, P. H. 1981. A functional approach to the phylogeny of the pharyngognath Teleosts. - American Zoologist 21: 83-101.

Mayr, E. 1981. Biological classification: toward a synthesis of opposing methodologies. - Science 214: 510-516.

Markle, D. F. and Olney, J. E. 1990. Systematics of the Pearlfish (Pisces: Carapidae). - Bulletin of Marine Science 47: 269-410.

Meyer-Rochow, V. B. 1979. Stomach and gut content of Carapus mourlani from starfish and a holothurian. - Annales of Zoologici Fennici 16: 287-289.

Motta, P. J. and Kotrschal, K. M. 1992. Correlative, experimental and comparative evolutionary approaches in ecomorphology. Netherlands fournal of Zoology 42: 400-415. 
Munro, I. S. R. 1967. The Fishes of New Guinea. Department of Agriculture, Stock, and Fisheries, Port Moresby, New Guinea.

Murdy, E. O. and Cowan, M. E. 1980. Observation on the behaviour and symbiotic relationship of the pearlfish Encheliophis vermicularis (Osteichthys: Carapidae). - Philippine fournal of Biology 9: 309-312.

Nelson, J. S. 1994. Fishes of the World. 3rd edn. John Wiley \& Sons, Inc., New York.

Norton, S. F., Luczkovich, J. J. and Motta, P. J. 1995. The role of ecomorphological studies in the comparative biology of fishes. Environmental Biology of Fishes 44: 287-304.

Paredes-Rios, G. A. and Balart, E. F. 1999. Corroboration of the bivalve, Pinna rugosa, as a host of the pacific pearlfish, Encheliophis dubius (Ophidiiformes: Carapidae), in the Gulf of California, Mexico. - Copeia 1999(2): 521-522.

Parmentier, E., Chardon, M., Poulicek, M., Bussers, J. C. and Vandewalle, P. 1998. Morphology of the buccal apparatus and related structures in four species of Carapidae. - Australian Fournal of Zoology 46: 391-404.

Parmentier. E., Castro-Aguirre, J. L. and Vandewalle, P. 2000. Cranial osteology and musculature in two bivalve commensal Teleostei: Encheliophis dubius and Onuxodon fowleri (Carapidae, Ophidiiformes). - Zoomorphology 120: 29-37.

Sanderson, S. L. 1990. Versatility and specialization in labrid fishes: ecomorphological implication. - Oecologia 84: 272-279.

Shen, S. C. and Yeh, H. S. 1987. Study on Pearlfishes (ophidiiformes: Carapidae) of Taiwan. - Fournal of the Taiwan Museum 40: $45-56$.

Smith, C. L. 1964. Some Pearlfishes from Guam, with notes on their ecology. - Pacific Science 18: 34-40.

Smith, C. L. and Tyler, J. C. 1969. Observations on the commensal relationship of the western Atlantic pearlfish, Carapus bermudensis, and holothurians. - Copeia 1969: 206-208.

Smith, C. L., Tyler, J. C. and Feinberg, M. N. 1981. Population ecology and biology of the pearlfish (Carapus bermudensis) in the lagoon at Bimini, Bahamas. - Bulletin of Marine Science 3: 876902.

Smith, J. L. B. 1955. The fishes of the family Carapidae in the Western India Ocean. - Annals and Magazine of Natural History 12 Ser. 8: 401-416.

Strasburg, D. W. 1961. Larval carapid fishes from Hawaii, with remarks on the ecology of adults. - Copeia 1961: 478-480.

Swofford, D. L. 1993. PAUP: Phyolgenetic Analysis Using Parsimony, Version 3.1.1. Illinois Natural History Survey, Champaign, IL.

Swofford, D. L. and Begle, D. P. 1993. PAUP: Phyolgenetic Analysis Using Parsimony, Version 3.1.1. User's Manual. Illinois Natural History Survey, Champaign, IL.

Taylor, W. R. and Van Dyke, G. C. 1985. Revised procedure for staining and clearing small fishes and other vertebrates for bone and cartilage study. - Cybium 2: 107-119.

Trott, L. B. 1970. Contribution of the Biology of Carapid Fishes (Paracanthopterygian: Gadiformes). - University California Publications in Zoology 89: 1-41.

Trott, L. B. 1981. A general review of the pearlfishes (Pisces, Carapidae). - Bulletin of Marine Science 31: 623-629.

Trott, L. B., Garth, J. S. 1970. Lissocarcinus orbicularis Dana (Portunidae, Caphyrinidae), commensal with Holothuria argus Jaeger - A new host record; cohabitation with the pearlfish, Carapus homei (Richardson). - Crustaceana 19: 320-321.

Trott, L. B. and Trott, E. B. 1972. Pearlfishes (Carapidae: Gadiforme) collected from Puerto Galera, Minobra, Philippines. - Copeia 1972: $839-843$.

Turingan, R. G. 1994. Ecomorphological relationship among Caribbean tetraodontiform fishes. - Fournal of Zoology 223: 493518.

Tyler, J. C. 1970. A redescription of the inquiline carapid fish Onuxodon parvibrachium, with a discussion of the skull structure and host. - Bulletin of Marine Science 29: 148-164.

Tyler, J. C., Robins, C. R., Smith, C. L. and Gilmore, R. G. 1992. Deepwater populations of the western atlantic pearlfish Carapus bermudensis (Ophidiiformes: Carapidae). - Bulletin of Marine Science 51: $218-223$.

Van Den Spiegel, D. and Jangoux, M. 1989. La symbiose entre poissons Carapidae et Holoturies autour de l'île de Laing (Mer de Bismarck, Papouasie Nouvelle Guinée). - Indo-Malayan Zoology 6: $223-228$.

Vandewalle, P. and Chardon, M. 1981. Réflexion sur les rapports entre forme, structure et fonction chez les poissons de la famille des Cyprinidae. - Cybium 5: 15-33.

Vandewalle, P., Parmentier, E., Poulicek, M., Bussers, J. C. and Chardon, M. 1998. Distinctive anatomical features of the branchial basket in four Carapidae species (Ophidiiformi, Paracanthopterygii). - European fournal of Morphology 86: 153-164.

Van Meter, V. B. and Ache, B. W. 1974. Host location by the pearlfish Carapus bermudensis. - Marine Biology 26: 379-383.

Wainwright, P. C. 1998. Morphology and ecology: functional basis of feeding constraints in Carribean labrid fishes. - Ecology 69: 635-645.

Westneat, M.W. 1995. Phylogenetic systematics and biomechanics in ecomorphology. - Environmental Biology of Fishes 44: 263-283.

Williams, J. T. 1983. Synopsis of the pearlfish subfamily Pyramodontinae (Pisces: Carapidae). - Bulletin of Marine Science 33: $846-854$.

Williams, J. T. 1984. Synopsis and phylogenetic analysis of the pearlfish subfamily Carapinae (Pisces: Carapidae). - Bulletin of Marine Science 34: 386-397. 